\title{
METAPHORIC TRANSFORMATION \\ OF HISTORICAL NAUTICAL TERMS INTO CONTEMPORARY ENGLISH COLLOQUIALISMS
}

\section{Nikulina O. L.}

\section{INTRODUCTION}

The origin of contemporary English colloquial language has its roots in various layers of historical and professional etymological sources of the English language, but since Britain was always a sea country and a marine power depending on the surrounding seas, the large bulk of contemporary colloquialisms descend from marine domain. The sea served always as means of island protection from the invaders and British people depended on the sea as a considerable source of food, like catch of fish. Britain always had a strong elaborate fleet that helped the country not only to defend itself but also to open new lands and make them British colonies, like Canada, Australia, India, etc. No wonder that many everyday English phrases are of nautical/ marine origin. In this research we studied binomials, phrasal verbs and idioms of nautical origin and decided to systemize them according to grammatical construction and stylistic meaning. Not many languages can boast such amount of nautical/marine words and phrases as the English language. The astonishing amount of English idiomatic speech owes to the nautical language of the past. English is extraordinary rich in metaphor and many of the figures of speech that people speaking English use every day derive from the language and customs of the sea which fact sometimes we even don't realize. This article is the first attempt of tracing the metaphoric transformation of historical nautical terms into contemporary English colloquials and of systematizing them according to two criteria: grammatical constructional and stylistically idiomatic. The big part of the studied marine terms is connected with sailing era of British fleet history, with the hostile elements that haunted the seamen at sea, with ships themselves with their structural parts, and with places originally inherent to human beings dwelling on land. At the time when the first ships appeared and the first voyages started to be organized, the mariners 
didn't have any maps or navigational aids, they relied mostly on their intuition, professional experience and skills.

The English language is a unique example of word formation and in general vocabulary building due to different professional and craft sources. In this article we shall investigate how nautical/marine language influenced the formation of contemporary English colloquialisms and idioms. The majority of people speaking English today do not realize that the origin of everyday phrases like: to stand by, high and dry, to be taken aback, to go ahead, etc. roots back to nautical/marine language. In our previous articles we studied this bulk of the language of nautical origin from the view point of their functional ${ }^{1}$, denominative ${ }^{2}$ and stylistic ${ }^{3}$ characteristics. In this article we'd like to research another field - structural, grammar field. We studied more than 40 different contemporary English colloquialisms, idioms and phrasal verbs and decided to subdivide them structurally into 3 groups:

1. Binomials.

2. Phrasal verbs.

3. Pure idioms.

We hope that this article will trigger the interest not only of the seafarers and people related to the marine business, but also to all those interested in the etymology of marine/nautical ESP.

\section{Binomials as metaphoric transformation of historic nautical terms into contemporary colloquial English}

The first group that we shall observe and describe here is binomials, which is "a pair of nouns joined by a word like "and", where the order of nouns is always the same" . Binomials are very frequently used in the English language, but as we mentioned before not many speakers realize that such popular phrases like "touch and go", "high and dry", fair and square, etc. owe their origin to nautical language. Here we shall mention ten of such expressions.

The colloquialism "by and by" nowadays means after a short time, soon, in the near future; ${ }^{5}$ after a little time; before long, the point is that

1 Hornby A.S. Oxford Advanced Learner's Dictionary of Current English. Oxford university Press, 2005. 1715 p.

${ }^{2}$ Ibid ; Random House Webster's College Dictionary. USA, 1995. 1555 p.

${ }^{3}$ Ibid.

4 Hornby A.S. Oxford Advanced Learner's Dictionary of Current English. Oxford university Press, 2005. 1715 p.

${ }^{5}$ Dictionary of English Language and Culture. London Group UK, 1992. 1528 p. 
this colloquialism has a nautical origin. To sail a vessel "by the wind" is to sail her as close to the wind as she will go. A seaman says that his ship is sailing "by and by" when she is making very slow progress against the wind. ${ }^{6}$ The doubling of "by" is an intensifier. This example shows clearly that the expression is of everyday use but is of marine origin.

Another expression of the kind is "by and large" which today means "all things considered, generally speaking" this colloquialism derives its meaning from the idea of compromise. in the nautical sense that meant that if a ship sailed a little off the wind she was said to be sailing "by and large".

The expression "high and $\boldsymbol{d r y}$ " is often used in contemporary colloquial English in the meaning of "in a helpless situation, in a difficult situation without help or money", in British English and "deserted, stranded" in American English As a nautical term it was said of a ship that has run aground so that the tide gradually exposes the keel. If this happens at high water the situation is pretty tragic, because there is no higher tide expected so the ship is bound to remain on ground until some extra help come to rescue it. This phrase gave the origin to the colloquial interpretation of "someone being left stranded, helpless, in a difficult position, unable to continue normally" colloquial nowadays and means "narrow escape, risky, of uncertain result", "precarious or delicate state of affairs" "Touch and go" being originally a nautical term, means "to run a vessel aground but to refloat her almost immediately", "it is to graze the bottom very slightly, in such a way as not to cause any serious damage or even check the vessel's progress through the water". That's why metaphorically now the phrase means "a narrow escape".

The expression "fair and square" in modern colloquial English may mean either honestly justly, straightforwardly and according to the rules or in a direct way that is easy to understand in nautical slang "fair", "which is to adjust and adapt something until it exactly suits the intended purpose; and "square" - to adjust it so that it lies at right angles to the fore-and-aft line of the ship"

${ }^{6}$ Jeans P.D. An Ocean of Words. A Dictionary of Nautical Words and Phrases. Toronto, Ontario : Carol Publishing Group, 1998. 180 p.

${ }^{7}$ Ibid.

${ }^{8}$ Ibid.

${ }^{9}$ Hornby A.S. Oxford Advanced Learner's Dictionary of Current English. Oxford university Press, 2005. 1715 p.

${ }^{10}$ Jeans P.D. An Ocean of Words. A Dictionary of Nautical Words and Phrases. Toronto, Ontario : Carol Publishing Group, 1998. 180 p. 
travelled into colloquial English in another phrase - "fair enough" and the word "square" - in expressions "to square off", "square away" meaning to make everything tidy.

Another interesting expression which practically all people speaking English would know is "free and easy" - informal and relaxed, but in marine English it means when the ship is sailing with the wind blowing over the stern quarters, so that the ship will sail along with the wind, practically without any resistance of the wind. Hence the colloquialism to be free and easy meaning to be informal, casual, without restraint or hindrance; in a relaxed manner ${ }^{11}$.

In the beginning of this part of the article we mentioned that binomials, is "a pair of nouns joined by a word like "and", where the order of nouns is always the same" ${ }^{\prime 2}$. But the next example is rather an exception to the rule, because this binomial can be read both: offand on and on and off. Colloquially this phrase means "now and then", occasionally, not regularly, not continuously. ${ }^{13}$ The expression is connected with nautical origin and originally it referred to a vessel's deliberate tactic of sailing toward the land (on) and then sailing away from it (off). ${ }^{14}$ This maneuver was done when the ship was waiting for a pilot or at night the vessel wanted to escape the risk of entering an unfamiliar harbor.

Another binomial connected with ship history is "to cut and run". It's easily interpreted nowadays and connected with the idea of "making a quick or sudden escape", the meaning being transparent that someone has to cut something before running away. ${ }^{15}$ This nautical term dates back to the $17^{\text {th }}$ century of sailing vessels. Before moving from the place of potential danger, from a harbor or elsewhere hazardous because of the approach of an enemy the ship had to first cut its anchor cable which was pretty tough thing to do quickly because the anchor was attached to the ship with a very heavy rope. Weighing the anchor and stowing the cable

${ }^{11}$ Jeans P.D. An Ocean of Words. A Dictionary of Nautical Words and Phrases. Toronto, Ontario : Carol Publishing Group, 1998. P. 60.

12 Hornby A.S. Oxford Advanced Learner's Dictionary of Current English. Oxford university Press, 2005. 1715 p. P. 135.

${ }^{13}$ Oxford Idioms. Dictionary of Learners of English. Oxford University press, 2020. 470 p.

${ }^{14}$ Jeans P.D. An Ocean of Words. A Dictionary of Nautical Words and Phrases., Toronto, Ontario : Carol Publishing Group, 1998. 180 p. P. 111.

15 Oxford Idioms. Dictionary of Learners of English. Oxford University press, 2020. 470 p. P. 79. 
below was normally a long and tedious business. Originally the expression derives from the practice of square-rigged ships. When the need to get underway was urgent the sails could be quickly set by sailors cutting the light rope-yarns. The sails would immediately hang free from their yards and the ship ready for instant departure. ${ }^{16}$

One more binomial that we want to trace the origin here is "spick and span" which in contemporary colloquial English means "clean, tidy and fresh". ${ }^{17}$ As the title and the idea of the article may suggest, the expression also owes its origin to marine/nautical English. It meant "quite new, of recent manufacture". ${ }^{18}$ In the days of wooden sailing ships a "spic" was a nail or spike, and a "span" was a chip of wood stuck from a length of timber. So "spick and span" was freshly built, brand new.

\section{Phrasal verbs as metaphoric transformation}

\section{of historic nautical terms into contemporary colloquial English}

The second group is phrasal verbs, which is "verb combined with an adverb or a preposition, or sometimes both, to give a new meaning"19. This is another group that we claimed at the beginning of our article as a target group for research in the field of describing the contemporary English colloquials was phrasal verbs. Technically and grammatically they are phrasal verbs as they are defined in British dictionaries: "verb combined with an adverb or a preposition, or sometimes both, to give a new meaning" 20 . To be exact, we should talk about a postposition, not a preposition because the word occupies the place after not before the verb. But since our research lies in the proximity of nautical origin of such phrasal verbs, of course they all will be connected with the marine history of such constructions.

The first example of such constructions that we will describe here is "to go ahead" which is explained in the Oxford Phrasal Verbs Dictionary as "to go in front of other people who are going in the same direction as you and

${ }^{16}$ Jeans P.D. An Ocean of Words. A Dictionary of Nautical Words and Phrases. Toronto, Ontario : Carol Publishing Group, 1998. 180 p. P. 138.

${ }^{17}$ Oxford Idioms. Dictionary of Learners of English. Oxford University press, 2020. 470 p. P. 372.

18 Jeans P.D. An Ocean of Words. A Dictionary of Nautical Words and Phrases. Toronto, Ontario : Carol Publishing Group, 1998. 180 p. P. 157.

19 Hornby A.S. Oxford Advanced Learner's Dictionary of Current English. Oxford university Press, 2005. 1715 p. P. 1092.

${ }^{20}$ Ibid. 
arrive before you", also "to be carried out or happen"21. It is interesting that in the Oxford Idioms Dictionary the phrase is not included as an idiom at all, but we found out that this colloquial expression has something to do with marine domain. Originally it was a purely nautical word, one of many that has a prefix " $a$ " indicating precisely the direction, "forward" "ahead". That's why one will find many marine expressions starting with this prefix, e.g. abreast, ahoy, astern, etc. ${ }^{22}$ Ahead means in front of the ship, in the direction where she is pointing, "to go ahead" means "to move forward".

Next phrasal verb that we shall consider here will be "to be taken aback". To take somebody aback is interpreted by Oxford Phrasal verbs Dictionary as "to shock or surprise somebody",23 It is interesting that Oxford Idioms Dictionary did not include this entry as an idiomatic one, but it definitely has nautical roots. The sails of a square-rigger were said to be "aback" when the wind was blowing directly on the wrong or foremost side of the sails. ${ }^{24}$ That could cause considerable damage to the ship's rigging. Colloquially, the term means to be surprised or confronted with an unexpected situation.

One more frequently used phrasal verb in the colloquial English language is "to stand by" which is interpreted as "to be present when something bad or unpleasant is happening, but not become involved" or "to be ready to take appropriate action" 25 .

The similar expression is included into the Dictionary of Oxford Idioms in the form of not a phrasal verb but a typical idiom - "on standby" - ready to do something immediately if needed or asked ${ }^{26}$. A very common nautical expression as in "stand by for further instructions", "stand by for the weather report" which means "to wait in a state of readiness", "to be ready to give assistance if needed" ${ }^{27}$. It is

${ }^{21}$ Oxford Phrasal Verbs. Dictionary for Learners of English. Oxford University Press, 2017. 398 p. P. 136.

22 Jeans P.D. An Ocean of Words. A Dictionary of Nautical Words and Phrases. Toronto, Ontario : Carol Publishing Group, 1998. 180 p. P. 5.

${ }^{23}$ Oxford Phrasal Verbs. Dictionary for Learners of English. Oxford University Press, 2017. 398 p. P. 324.

${ }^{24}$ Jeans P.D. An Ocean of Words. A Dictionary of Nautical Words and Phrases. Toronto, Ontario : Carol Publishing Group, 1998. 180 p. P. 4.

${ }^{25}$ Oxford Phrasal Verbs. Dictionary for Learners of English. Oxford University Press, 2017. 398p. P. 305.

${ }^{26}$ Oxford Idioms. Dictionary of Learners of English. Oxford University press, 2020. 470 p. P. 77.

27 Jeans P.D. An Ocean of Words. A Dictionary of Nautical Words and Phrases. Toronto, Ontario : Carol Publishing Group, 1998. 180 p. P. 158. 
interesting that an expression "a standby" which is now a supporter, something kept in readiness, was originally an attendant ship, a smaller vessel that stood by a larger vessel, to act as messenger, escort, etc. ${ }^{28}$

The next but not less interesting historical expression that entered the contemporary English and definitely has connection with nautical English is "to pay off". As for the phrasal verbs interpretation it means "to give somebody money to persuade them not to do something or not to tell somebody about something illegal or dishonest that you have done" 29 . The expression "standby" or "on standby" is included into the Dictionary of Idioms and the suggested explanations are: "ready to do something immediately if needed or asked". ${ }^{30}$ Originally "to pay off" was to close the accounts of a naval ship when she reached the end of commission. ${ }^{31}$ The point is that the ship's companies of those days were given the balance of moneys. That was really a battle between banks and ships, but usually the seamen were not denied their regular wages. Now in the colloquial sense the phrase "to pay someone off" is to get even, to pay off an old score. ${ }^{32}$

The two phrasal verbs that we want to examine here will be "pipe down" and "pipe up". The Oxford Phrasal verbs dictionary interprets "pipe down" as be less noisy, stop talking, and "pipe up" as an antithesis to the previous one like to begin to speak. ${ }^{33}$ Needless to say that the two phrases originated on board ship. In naval vessels orders were given and recognized by the individual pattern of notes piped on a whistle - known as the boatswain's call; "pipe down" was the last blow of the whistle for the day and meant the order for unwanted lights to be switched out, unnecessary noise and activity to stop, so that those preparing for night watches could go sleeping. The term has been adopted by sailors and is used when they want someone to stop talking or

${ }^{28}$ Jeans P.D. An Ocean of Words. A Dictionary of Nautical Words and Phrases. Toronto, Ontario : Carol Publishing Group, 1998. 180 p. P. 159.

${ }^{29}$ Oxford Phrasal Verbs. Dictionary for Learners of English. Oxford University Press, 2017. 398 p. P. 220.

${ }^{30}$ Oxford Idioms. Dictionary of Learners of English. Oxford University press, 2020. 470 p. P. 377.

${ }^{31}$ Jeans P.D. An Ocean of Words. A Dictionary of Nautical Words and Phrases. Toronto, Ontario : Carol Publishing Group, 1998. 180 p. P. 119.

32 Jeans P.D. An Ocean of Words. A Dictionary of Nautical Words and Phrases. Toronto, Ontario : Carol Publishing Group, 1998. 180 p.

33 Oxford Phrasal Verbs. Dictionary for Learners of English. Oxford University Press, 2017. 398 p. P. 227. 
making a nuisance of themselves. ${ }^{34}$ The expression "to pipe up" is the opposite in meaning to the expression "pipe down" in colloquial contemporary sense, but in nautical context it meant not "to speak up" as it is now, but "to call from the boatswain pipe the watch from below to their duties on deck". 35

In this article and in our previous ones we often stressed upon the fact that people speaking English often use the terms, phrases, idioms, even slang of nautical origin never being aware of that. A good example is a neutral word "forge" being used as two parts of speech, noun and verb. Definitely we'll be interested in the meaning of "forge" as a verb, because here we investigate phrasal verbs. So "forge" means "to put a lot of effort into making something successful or strong so it will last". ${ }^{36}$ So we can see that the key implication of the word "forge" is "effort". The verb has entered into the Phrasal verbs dictionary as a phrase "forge ahead" - to move forward quickly, to make progress quickly. ${ }^{37}$ Here we can observe that the focus of meaning is shifted to the predominant meaning "quickly" which can be explained after studying the history of nautical/marine terms. A vessel was said "to forge ahead" when she was moving rapidly under a full press of canvas. Colloquially "to forge ahead" is to carry on with one's purpose and direction. ${ }^{38}$ It is interesting to mention that there is a close marine phrasal verb with an opposite meaning - "to forge over" which meant to force a ship violently over a shoal by effort of a large amount of sails. Maybe that was the key impulse to introduce the idea of "effort" in today's neutral verb "forge".

None the less interesting example is the phrasal verb "to go overboard". From the structure of the phrase we can judge that it is a phrasal verb, but there is no such entry in the Oxford Phrasal Verbs dictionary, but we found such an entry in the Oxford Idioms dictionary under the entry of "overboard" which really sounds like an idiom. It means "to be too excited or enthusiastic about something or about doing

${ }^{34}$ Beavis B., McGloskey R.G. Salty Dog Talk. The Nautical Origin of Everyday Expressions. London : Sheridan House ; New York : Granada, 1983. 96 p.

${ }^{35}$ Jeans P.D. An Ocean of Words. A Dictionary of Nautical Words and Phrases. Toronto, Ontario : Carol Publishing Group, 1998. 180 p. P. 121.

${ }^{36}$ Hornby A.S. Oxford Advanced Learner's Dictionary of Current English. Oxford university Press, 2005. 1715 p. P. 583.

${ }^{37}$ Oxford Phrasal Verbs. Dictionary for Learners of English. Oxford University Press, 2017. 398 p. P. 117.

${ }^{38}$ Jeans P.D. An Ocean of Words. A Dictionary of Nautical Words and Phrases. Toronto, Ontario : Carol Publishing Group, 1998. 180 p. P. 59. 
something". ${ }^{39}$ Let's turn back again to the explanation from the nautical background. "Board" means bord or plank; "to go overboard" meant that something had fallen over the side of the ship. "Man overboard" means that someone has fallen out into the water. In figurative meaning the phrase "to go overboard" means "to harbor an excess of feeling about something, to lose one's emotional footing". 40

The word "mess" is quite popular in colloquial English in the meaning of "untidy state", "difficult situation", etc. ${ }^{41}$ It also entered the field of phrasal verbs in the variations of : mess about/around - to treat somebody badly, making them waste time, changing your mind a lot; mess around with something - to keep touching or moving something in an annoying way; to mess up - to spoil something, to get involved in something that you do not know much about, etc. ${ }^{42}$ The word entered the idiom "make a mess - do something very badly". 43

Many English people will find it strange, but the origin of the word lies within the ocean of nautical/marine English. All seafarers nowadays associate the word "mess" with "mess room", which is 'a place aboard ship where people have meals', mostly ratings, because officers take their meals in saloons or halls. We got interested how so inoffensive and positively charged word with positive connotation meaning "meal" (from Latin) could come into the everyday colloquial English with prominent negative connotation'. We found out that historically all seamen ate together in dimly lit, badly aired spaces below decks; there they often fought and drank: they were treated as dregs by their officers, who definitely ate separately. Originally the term "mess" referred to a portion of food, but traditionally the remnants of not eaten food were mixed together which suggests the idea of a jumble or confusion. Colloquially the word "mess" also meant a group of people sitting together and eating from the same dishes. In this sense the word derives from the crowded

${ }^{39}$ Oxford Idioms. Dictionary of Learners of English. Oxford University press, 2020. 470 p. P. 276.

${ }^{40}$ Jeans P.D. An Ocean of Words. A Dictionary of Nautical Words and Phrases. Toronto, Ontario : Carol Publishing Group, 1998. 180 p. P. 115.

${ }^{41}$ Hornby A.S. Oxford Advanced Learner's Dictionary of Current English. Oxford university Press, 2005. $1715 \mathrm{p}$.

${ }^{42}$ Oxford Phrasal Verbs. Dictionary for Learners of English. Oxford University Press, 2017. 398 p. P. 204.

${ }^{43}$ Oxford Idioms. Dictionary of Learners of English. Oxford University press, 2020. $470 \mathrm{p}$. 
and confusing nature of the mess as a mess-hall. ${ }^{44}$ That explains why the colloquials "mess about/around" came to mean "to busy oneself in an untidy or confused way".

All English speaking people know what "a kite" is, and many used to fly a kite when a child. Now it's not very popular but it used to be a kind of a toy that you fly in the air using one or more strings. The kite would tell a child which way the wind was blowing. This harmless toy entered the bulk of contemporary English idioms as an expression "to fly a kite", which means "release a bit of information in order to test public reaction to something that you plan to do at a later date" 45 . In the sailing ships" history "kite" was the general name given to the light-weather square sails that could be spread at the masthead to make the most of light following winds. ${ }^{46}$ Hence the meaning of the today idiom is transparent: "to fly a kite" means to hoist such a sail that was meant literally to see what would happen, to see whether any improvement could be made in the vessel's speed. So here lies the origin of an idiom "to fly a kite" - to test the public reaction to an idea or a plan.

The next phrasal verbs that we'll consider here are "to be overrated" and "to be underrated". They are very common in their neutral meanings that we can find in any dictionary, e.g. "to overrate" - to have too high an opinion of somebody or something; ${ }^{47}$ "to underrate" - to not recognize how good, important, etc. somebody/something really is ${ }^{48}$. The origin of this idiom roots back also to nautical/maritime terminology. The rank held by a naval seaman is known as a "rate" and the man himself as a "rating". Each seaman had a rate according to his ability. A boy first entering a ship would be an ordinary seaman (first rate) ${ }^{49}$. Then according to his work, diligence and abilities he could be promoted to a higher rank, like leading seaman, petty officer, etc. In case of severe disobedience or incompetency the captain had a prerogative to derate the

44 Jeans P.D. An Ocean of Words. A Dictionary of Nautical Words and Phrases. Toronto, Ontario : Carol Publishing Group, 1998. 180 p.

${ }^{45}$ Oxford Idioms. Dictionary of Learners of English. Oxford University press, 2020. 470 p. P. 133.

46 Jeans P.D. An Ocean of Words. A Dictionary of Nautical Words and Phrases. Toronto, Ontario : Carol Publishing Group, 1998. 180 p. P. 87.

47 Hornby A.S. Oxford Advanced Learner's Dictionary of Current English. Oxford university Press, 2005. 1715 p. P. 1058.

${ }^{48}$ Ibid. P. 1607.

49 Hornby A.S. Oxford Advanced Learner's Dictionary of Current English. Oxford university Press, 2005. 1715 p. P. 116. 
seaman to a lower rating, so that the seaman was "over-rated". Derating was a common means of punishment, a disciplinary measure. In a similar fashion the captain could grant a seaman a promotion for a good job, so the seaman was granted a promotion to a higher rate, he was "underrated". So we have the metaphors that have been derived from this nautical practice: "to be overrated" is to be overestimated, "to be underrate" to be undervalued.

\section{Idioms as metaphoric transformation}

\section{of historic nautical terms into contemporary colloquial English}

English language is one of the most metaphoric and idiomatic language, that's why no wonder that this group encounters the majority of entries.

Our interest to this group was provoked by the fact that few people realize what stands behind such expressions as "take it easy", "high and dry", "ship-shape", "dire straits", etc. although the close look definitely suggests something connected with the sea and seafarers.

It is always interesting for a researcher to find etymological roots of the expressions that we use nowadays. We'll start here with the definition of "idiom" and what is the term's main difference from such close linguistic terms as "colloquialism", "slang", "phrasal verbs", "jargon etc.". While "colloquial" means a phrase or a word which is used in informal conversation, but not in formal speech; "slang" is interpreted by many dictionaries as very informal, brand new, not very polite words used among particular groups of people; "phrasal verbs" as the term speaks by itself is a verb followed by a preposition (postposition word would be more correct) which changes the meaning of the whole phrase, sometimes drastically; "jargon" is specific vocabulary of different professions (seafarers, doctors, lawyers); "idiom" is something really different.

Since the target of the given article is "idioms" it is but necessary to define what an idiom means. Addressing the profound and honored dictionaries we found the following definitions: "a group of words whose meaning is different from the meaning of the individual words" phrase which means something different from the meanings of the separate words from which it is formed"51, "an expression whose

50 Hornby A.S. Oxford Advanced Learner's Dictionary of Current English. Oxford university Press, 2005. 1715 p. P. 140.

${ }^{51}$ Dictionary of English Language and Culture. London Group UK, 1992. 1528 p. 
meaning is not predictable from the usual grammatical rules of a language or from the usual meanings of its constituent elements" "peculiar mode of expression" 53 [5, p. 226]. We think that although the sources are very reliable, the definitions of an idiom sound a bit ambiguous and for an inquisitive person, who relies on his logic, may mean nothing substantial. We take the liberty here to suggest our own definition to an "idiom". An idiom is an expression that simultaneously realizes two meanings: the direct one and the metaphorical one, but the second metaphorical meaning is contemporarily predominant and usually people immediately think about the metaphorical and not direct meaning when they hear an idiom. For example, we may presume that somebody may bring a bag someplace with a cat inside and then let the cat go, but why would somebody carry cats in bags nowadays? It seems ridiculous. Automatically in this case people would think of the idiomatic meaning of the phrase - "to reveal a secret".

Here we shall reveal a secret of the idiom "to let the cat out of the bag" from the nautical point of view. The expression "to let the cat out of the bag" is a widely used colloquial one and means "to tell a secret carelessly or by mistake". This metaphor also takes its roots in nautical slang. "To let the cat out of the bag" was to put an unpleasant state of affairs into motion. The point is that the cat-o'-nine-tails' (nine-lashed whip used for punishing seamen) was traditionally kept in a bag made of baize, and when this "cat" was taken out of the sack it definitely meant the punishment was to arrive. The seamen had a specific ironic humor, so they compared the punishment tool with a purring domestic cat. Luckily, this colloquial expression of marine origin is not connected with punishment today.

Another idiom that many speakers can decipher is "between the devil and the deep blue sea". The phrase "between the devil and the deep blue sea" in metaphorical sense is used in contemporary English in the meaning of "facing two choices, both of which are unpleasant" ". The marine origin of the expression is easily detectable. The devil on board ship was the outermost seam on the deck, it was called so because it was practically impossible to hammer the caulking in to make the seam watertight. It is also the name of garboard seam between the keel and the first plant which was

${ }^{52}$ Random House Webster's College Dictionary. USA, 1995. 1555 p.

53 Walter W. Skeat, Concise Dictionary of English Etymology. Wordsworth Reference, 2007.643 p. P. 226.

${ }^{54}$ Ibid. P. 348. 
also difficult to caulk. For the sailor all that lay between disaster and his present position was the thickness of the planking that stood between the devil on the deck and the sea around the ship. "The "deep blue sea" was the inevitable dire result if the sailor neglected to carry out the necessary and always difficult task of keeping the devils in good order" ${ }^{25}$. That's how the metaphor appeared, - to be placed between two alternatives, each of which is equally precarious or hazardous.

One more interesting idiom is "there are plenty more fish in the sea" which means "there are many other people or things that are as good as the one somebody has failed to get" the meaning of the big basin of salty water covering the Earth surface is "the ocean", the word which also gave birth to many contemporary English idioms. "An ocean of something” means a large amount of something and often is not connected with an ocean at all, like in the phrase "an ocean of food" which means just plenty of food. Another frequently used idiom is "a drop in the ocean" which exists in many languages and means a very small amount in comparison to the much bigger amount which is needed, i.e. - practically nothing.

Sea and ocean associates with salty waters, no doubt the word "water" enters many English idioms that have the marine roots. The idiom "in deep waters" is easily read as something not very safe and trouble making. The idiom means to be in trouble or difficulty.

Nowadays with all the modern gadgets and navigational computerized systems the good weather may not be as vitally important as it used to be in the era of sailing ships, when the life of people and the vessel directly depended on good wind and weather. That is why we can find the word "weather" in contemporary English idioms. A well-known idiom/colloquialism "to be under the weather" can be easily decoded as to be under the influence of bad weather, to feel blue, to feel unwell. It is also a colloquialism for being inebriated, drunk. But the phrase is definitely connected with the sea and this is transparent. Usually when the sea is rough and it's storming even not heavily, landsmen may be inclined to seasickness, nausea, which is the visible symptom of being under the influence of the weather. The traditional belief is that seamen

55 Hornby A.S. Oxford Advanced Learner's Dictionary of Current English. Oxford university Press, 2005. 1715 p. P. 36.

${ }^{56}$ Oxford Idioms. Dictionary for learners of English. Oxford University Press, 2020. 469 p. P. 129. 
do not succumb to seasickness, although "Lord Nelson himself freely admitted to being seasick for a day or two whenever he went to sea". 57

The word "wind" is also very popular in many English idioms and definitely it comes from marine language of the sailing ships era. One of the vivid example may be "to take the wind out of somebody's sails", the idiom means to make somebody suddenly less confident or angry, especially when people do not expect bad news. This metaphor meant that all of a sudden the wind at sea changed drastically or just died out and the ship could not proceed because the sails dropped dead. Another example that should be mentioned here is the idiom "sail close to the wind" which means to behave in a way that is almost illegal or socially unacceptable.

Another marine word that enters the first group is "storm". Definitely ships even nowadays prefer to escape the storms at sea because their damage is usually unpredictable. That's why the idioms that contain the word "storm" describe something very unpleasant, unpredictable, extreme or of emergency kind. The idiom "the calm/lull before the storm" is pretty transparent and means a period of unnatural calm before an attack, violent activity, and not only at sea, but in business situation or whatever. It is interesting to trace here that the word "storm" originates from ME "stir" (stiren) which meant "to disturb, to scatter, destroy"; now literally "storm" means "that which lays low" "storm" is first and foremost associated with very bad weather mostly at sea, it entered many expressions and gave birth to the idioms which are not necessarily connected with marine/ nautical origin. For example, when people use the idiom "a storm in a teacup" they mean a small or unimportant problem which is treated much more seriously than it really should be. But it's only fair to say that one can find much more idioms in the contemporary English where the word "storm" would rather mean a difficult, deadlock situation, e.g., "ride out/weather the storm (of sth)" which means manage to survive a difficult period or situation.

One more typically nautical term is "strait" which means a narrow natural water passage between two pieces of land, like a Strait of Dover between the Great Britain and the continent. Historically on French charts and maps the same water space is called Pas de Calais. The point

57 Walter W. Skeat, Concise Dictionary of English Etymology. Wordsworth Reference, 2007. 643 p. P. 175.

${ }^{58}$ Oxford Idioms. Dictionary for learners of English. Oxford University Press, 2020. 469 p. P. 495. 
is that the broader part of the water distance between England and France is called the English Channel in English and La Manche in French. The word "strait" gave birth to a well-known idiom "dire straits" that means in contemporary English "to be in a very difficult situation and may go bankrupt" the future" 60 . Originally "dire straits" meant difficult, troublesome passage of water for the ship to pass, so when in the late 80-ies a rock group appeared with the name "Dire Straits" the contemporary young people may have sooner thought about the obstacles that the band had to overcome in the tough competition with the other rock bands. The group was pretty successful and they did overcome the competition of the time, but the young fans hardly

The next idiom that we are presenting here is very close to the previous in a sense that everything on the ship should be properly done according to the orders and standard requirements, ship-shape (by the way, this idiom also comes from maritime slang). The phrase is "shape up or ship out" which means directly on board ship "either use, obey and correspond to rules or you will be made redundant and dismissed from the ship. The idiom appeared in the contemporary English with a rather transparent meaning" if you do not work hard and do not try to improve you will have to leave the job or position ${ }^{61}$. The idiom is more frequent in American English.

Another idiom containing the seme "ship" contains humorous and disapproving connotation: “desert/leave a sinking ship". Usually animals are more sensitive to the changing weather conditions and they feel much sooner than people when their habitat may be exposed to danger. There is no secret that rats always accompanied sailing ships because there was plenty of food in the holds and the sanitary rules were practically neglected. The rats as wild animals were the first to leave a ship before the forthcoming danger, like sinking, shipwreck, fire, etc. Rats were always an object of despise with people mostly because they infected people with contaminable deadly diseases, that's why the word "rat" in colloquial contemporary English is associated with something disgusting, squeamish i.e. "rat" - an unpleasant person, especially one

59 Hornby A.S. Oxford Advanced Learner's Dictionary of Current English. Oxford university Press, 2005. 1715 p. P. 410.

60 Dictionary of English Language and Culture. London Group UK, 1992. 1528 p. P. 359.

${ }^{61}$ Oxford Phrasal Verbs. Dictionary for learners of English. Oxford University Press, 2017. 398 p. 
who is not loyal or who tricks somebody 62 "smell a rat" - think or suspect that something is wrong or somebody is trying to deceive you, "drowned rat" - very wet, "rat race" - intense competition for success in jobs, business, etc. In connection to the marine history usually it's a naval code, that in case of any emergency situation that may cause peoples' death and ship's sinking it is the captain of the ship who is the last to leave. The idiom now is used to talk about "people who leave an organization, a company that is having difficulties without caring about the people who are left".

The word "boat" may mean "a vehicle (smaller that a ship) that travels on water" 63 or it may be just a synonym to the word "ship". During our research we payed attention that although "boat" is not as popular a component of English idioms as "ship", still the word has entered many colloquial expressions. The expression that exists in many European languages is "to be in the same boat". Its meaning and its nautical origin is transparent: when people share the same boat with only water around and sometimes no means to escape, they are absolutely equal in front of the danger, be they rich or poor, black or white. This contemporary idiom means "to be in the same difficult position or situation as somebody else".

In the beginning of this article we mentioned the important fact about idioms: they realize simultaneously two of the meanings - direct and metaphorical. When we speak about the situation when we missed the last bus or train, it's very unpleasant if not irritating because we have to wait for the one tomorrow. Some languages, like Russian and Ukrainian have the expression "your train has gone" and it means "it's too late to do something to amend things". In English there is an expression which is practically synonymous: "to miss the boat" which means "to lose the opportunity to do or get something because you do not act quickly enough" ${ }^{4}$.

Another interesting idiom worth attention here is "burn your bridges/boats". Again the meaning of the idiom is clear: if one burns the bridges or boats behind him it will be impossible for him to retreat. Nowadays in English the expression means "to do something that makes

62 Hornby A.S. Oxford Advanced Learner's Dictionary of Current English. Oxford university Press, 2005. 1715 p.

63 Ibid.

${ }^{64}$ Oxford Idioms. Dictionary for learners of English. Oxford University Press, 2020. 469 p. P. 247. 
it impossible for you to return to a previous situation"; "to destroy all means of going back, so that one must go forward"

Since the history of nautical/marine language dates back to mainly the sailing era of seamanship, it is but obvious that one of the common and frequent word in pro-marine idioms will be "sail". If we look into the etymological dictionaries of the English language we'll find out that "sail" meant "that which endures or resists the wind". Let's find out whether the original meaning of the word is traced in the contemporary idioms. The first example of such idiom will be "trim your sails", which originally meant "to arrange the sails of your boat to suit the wind, so that the boat moves faster". In nowadays English the idiom means "to cut expenses, to economize".

Next interesting idiomatic expression to dwell about here is "to take the wind out of somebodies' sails". It's but natural that if there was no wind during the days of sailing vessels, sails were useless because the wind was the only power pushing the ship to move along the water. It is clear that if the wind is out of somebody's sails it's too bad, the dead alley situation. Nowadays the idiom means "to make somebody suddenly less confident or angry, especially when you do or say something that they do not expect" $"$.

Another interesting expression containing the seme "sail" is "it's all plain sailing" which has undergone the diametrically opposite transformation in the language just because of one-word mistake. The word "plain" in contemporary English means "easy, clear, honest, direct, simple". If we take this meaning into consideration the expression "plain sailing" would mean easy, simple sailing' and as an idiom today it means "simple and free from trouble", "anything straightforward and easy to do" "67. Historically the phrase referred to "plane sailing" which was "the art of determining a vessel's position on the assumption that the earth is flat and the ship is therefore sailing on a plane surface". So "plane" was transferred into "plain" because it was easier to plot the ship's course and to calculate the route on a plane chart.

"Mast" as a constructive part of the ship is very important today, but just imagine how important it was in the days of sailing fleet, because all

${ }^{65}$ Oxford Idioms. Dictionary for learners of English. Oxford University Press, 2020. 469 p. P. 157.

${ }^{66}$ Oxford Phrasal Verbs. Dictionary for learners of English. Oxford University Press, 2017. 398 p.

${ }^{67}$ Walter W. Skeat, Concise Dictionary of English Etymology. Wordsworth Reference, 2007. 643 p. P. 139. 
the sails were fixed to masts and the ships were named after the number of masts on board. No wonder "mast" is a popular entry to marine idioms. Here we'll explore the idiom "nail your colors to the mast". First of all, we need to explain that the word "color" in marine English means " a flag" of a country where the ship is registered. Now the idiom means "to show clearly which side you support" used to mean that a ship showed its intention to continue fighting in battle and not surrender by nailing its flag to the mast.

Another integral constructional part of the ship's construction is "deck", so definitely it entered the bulk of marine idioms. "Deck" on board ship is like floor in a house, so sometimes it is easy to decipher the meaning of the marine idioms, but sometimes not. For example, let's consider the idiom "clear the deck". Before doing something on deck, like cargo handling, mooring, bunkering the seamen have to clear the deck space from anything that may get in the way, hence the meaning of the idiom is clear - "to prepare for an activity, event by removing anything that is not essential"69.

One more interesting idiom with the word "deck" is "all hands on deck". In colloquial English the expression means that everyone should help or must help in case of emergency. The marine origin of this idiom may be traced not only from the term "deck" but also from the word "hand" which in marine language means "a sailor". This was a command given on board ship in case of unpredictable or complicated situation when all seamen free from watch or emergency work had to arrive on deck to their muster station and had to be ready to perform any commands from their seniors.

The word "deck" is often used in metaphorical sense as "any flat surface" like floor in the house, that's why in the expressions "hit the deck" the word means just "ground"; fall to the ground suddenly. In American version the idiom may also mean "to get out of bed".

The first word that gave birth to contemporary English idioms and which we'll examine here is "coast". And the first expression that we'll describe here will be "the coast is clear". Nowadays the expression means that there is no apparent likelihood of interference, there is no enemy in sight; "there is no one around to see or stop what you are

68 Walter W. Skeat, Concise Dictionary of English Etymology. Wordsworth Reference, 2007. 643 p. P. 255.

${ }^{69}$ Ibid. P. 261. 
doing"70; "nothing is present that would impede or endanger one's progress" ". The idiom stems from "the clear coast" that dates back to the days of smuggling. If the coast was clear, it meant that there was no coast guard or any other control services that would check for or interfere with smugglers' activities.

Another idiom that contains the word "coast" is "to coast along" which in contemporary English means "to put very little effort into something" (used in a disapproving sense). Historically this phrase is definitely connected with marine usage. "To coast" is to sail along the line of the coast; a coaster is a small ship like a pilot boat that sails between the harbors or adjacent coasts. Such vessels encountered few serious obstacles to a safe passage because they were always within the sight of land; they could fix their position with great accuracy and they could always find shelter in the nearby haven in case of bad weather. So it's clear that colloquial meaning of "to coast along" is to carry out a task with minimum effort, without unnecessary fuss or bother ${ }^{72}$.

Next idiom to undergo our description will be "no-man's land". The expression originated in marine slang and meant the space amidships of a vessel, between the after part of the forecastle and the foremast. In this place usually were kept the ropes and everything needed to work at the forecastle. The name derives from being neither on the starboard nor the port side. Later this term was applied to the area of land between hostile lines of entrenchments or to any space contested by both sides of the combatants and belonging to none. This idiom is used not only as the army slang but also as the contemporary colloquial English meaning "wildness, a place to be avoided as dangerous"

One more idiom worthwhile mentioning here is "to hit/reach rock bottom" or "be at rock bottom". Definitely its clear connection with marine language is seen with a naked eye. If a ship hits rock bottom it means that she has run aground which is a very unpleasant delay because sometimes the vessel would need the extra external assistance to tug her in the waters again. In contemporary English the idiom means "reach or

${ }^{70}$ Walter W. Skeat, Concise Dictionary of English Etymology. Wordsworth Reference, 2007. 643 p. ; Oxford Phrasal Verbs. Dictionary for learners of English. Oxford University Press, 2017, 398 p. P. 65.

${ }^{71}$ Random House Webster's College Dictionary, USA, 1995, 1555 p. P. 260.

72 Jeans P.D. An Ocean of Words. A Dictionary of Nautical Words and Phrases. Toronto, Ontario : Carol Publishing Group, 1998. 180 p.

${ }^{73}$ Ibid. P. 91. 
be at the lowest point or level that is possible" $"$. Another synonymous expression to the idiom above is "high and dry" which is often used in contemporary colloquial English in the meaning of "in a helpless situation, in a difficult situation without help or money" in British English and "deserted, stranded" in American English. As a nautical term it was said of a ship that has run aground so that the tide gradually exposed the keel.

An interesting metaphor which also contains the marine objects that we can find on land has entered the contemporary colloquial English language - "not the only pebble on the beach". The meaning is informal and disapproving "not the only person who is important or should be considered". The word "beach" also is a constituent of a colloquialism "beachcomber" which may mean either "a person who lives by gathering salable articles of jetsam, refuse from beaches" or "a vagrant who lives on the seashore"

Let's look at the expression "when your ship/boat comes in", definitely it is of a positive connotation, because when a seaman was waiting for a ship that could give him engagement, coming into the port and hiring him, that was a good sign. That is why nowadays the idiom means "when you are suddenly successful or have a lot of money"

It goes without saying that everything on board ship should be kept in good order and that is why one of the first and foremost rule with the seafarers. Otherwise the terrible thing may happen during a disaster. Everything on board should be kept an eye to and everything should be "tight and tidy". Hence the expression of marine origin which is clearly read now as "keep everything in good order" is "run a tight ship" which means "run a business, organization, etc. in a strict and efficient way"77. The next idiom that we are presenting here is very close to the previous in a sense that everything on the ship should be properly done according to the orders and standard requirements, ship-shape (by the way, this idiom also comes from maritime slang). The phrase is "shape up or ship out" which means directly on board ship "either use, obey and

74 Walter W. Skeat, Concise Dictionary of English Etymology. Wordsworth Reference, 2007. 643 p. ; Oxford Phrasal Verbs. Dictionary for learners of English. Oxford University Press, 2017. 398 p.

${ }^{75}$ Random House Webster's College Dictionary. USA, 1995. 1555 p.

76 Walter W. Skeat, Concise Dictionary of English Etymology. Wordsworth Reference, 2007. 643 p. ; Oxford Phrasal Verbs. Dictionary for learners of English. Oxford University Press, 2017, 398 p.

${ }^{77}$ Ibid. P. 410. 
correspond to rules or you will be made redundant and dismissed from the ship. The idiom appeared in the contemporary English with a rather transparent meaning" if you do not work hard and do not try to improve you will have to leave the job or position ${ }^{78}$. The idiom is more frequent in American English.

As was mentioned above the seme "ship" joined the bulk of English idioms not only with positive connotation, but with if not negative, then definitely not one on the pleasant side. The first example of such an idiom is "to jump the ship" / "to jump ship" which originally was a purely nautical term and meant "to leave the ship on which you are serving without permission",79, which of course was illegal and punishable. Nowadays the idiom means practically the same but is not connected with a ship, i.e. "to leave an organization that you belong to suddenly and unexpectedly". That careless action is usually not approved of and appraised by the administration. In the old days such sailors traitors were not in honor and sometimes it was difficult for them to find job on a different ship. The same situation is now, if somebody "jumps ship" from a prestigious company, he will be entered into a blacklist and it will be problematic for the person to find a decent job, at least in the same sphere.

Let's look at the expression "when your ship/boat comes in", definitely it is of a positive connotation, because when a seaman was waiting for a ship that could give him engagement, coming into the port and hiring him, that was a good sign. That is why nowadays the idiom means "when you are suddenly successful or have a lot of money" 80 .

It goes without saying that everything on board ship should be kept in good order and that is why one of the first and foremost rule with the seafarers. Otherwise the terrible thing may happen during a disaster. Everything on board should be kept an eye to and everything should be "tight and tidy". Hence the expression of marine origin which is clearly read now as "keep everything in good order" is "run a tight ship" which means 'run a business, organization, etc. in a strict and efficient way ${ }^{81}$.

78 Walter W. Skeat, Concise Dictionary of English Etymology. Wordsworth Reference, 2007. 643 p.

${ }^{79}$ Ibid.

${ }^{80}$ Walter W. Skeat, Concise Dictionary of English Etymology. Wordsworth Reference, 2007. 643 p. ; Oxford Phrasal Verbs. Dictionary for learners of English. Oxford University Press, 2017. 398 p. P. 349.

${ }^{81}$ Ibid. P. 411. 
The next idiom that we are presenting here is very close to the previous in a sense that everything on the ship should be properly done according to the orders and standard requirements, ship-shape (by the way, this idiom also comes from maritime slang). The phrase is "shape up or ship out" which means directly on board ship "either use, obey and correspond to rules or you will be made redundant and dismissed from the ship. The idiom appeared in the contemporary English with a rather transparent meaning" if you do not work hard and do not try to improve you will have to leave the job or position ${ }^{82}$. The idiom is more frequent in American English.

As was mentioned above the seme "ship" joined the bulk of English idioms not only with positive connotation, but with if not negative, then definitely not one on the pleasant side. The first example of such an idiom is "to jump the ship" / "to jump ship" which originally was a purely nautical term and meant "to leave the ship on which you are serving without permission" punishable. Nowadays the idiom means practically the same but is not connected with a ship, i.e. "to leave an organization that you belong to suddenly and unexpectedly". That careless action is usually not approved of and appraised by the administration. In the old days such sailorstraitors were not in honor and sometimes it was difficult for them to find job on a different ship. The same situation is now, if somebody "jumps ship" from a prestigious company, he will be entered into a blacklist and it will be problematic for the person to find a decent job, at least in the same sphere.

\section{CONCLUSIONS}

The object of the article was to study and describe the metaphoric transformation of historical nautical terms into contemporary English colloquials. During our research we subdivided the bulk of studied linguistic material structurally into 3 groups:

1. Binomials.

2. Phrasal verbs.

3. Pure idioms.

${ }^{82}$ Walter W. Skeat, Concise Dictionary of English Etymology. Wordsworth Reference, 2007. 643 p. P. 347.

${ }^{83}$ Walter W. Skeat, Concise Dictionary of English Etymology. Wordsworth Reference, 2007. 643 p. ; Oxford Phrasal Verbs. Dictionary for learners of English. Oxford University Press, 2017. 398 p. 
The first group, binomials, we considered as a pair of nouns joined by a word like "and", where the order of nouns is always the same. Binomials are very frequently used in the English language, but as we mentioned before not many speakers realize that such popular phrases like "touch and go", "high and dry", "fair and square", etc. owe their origin to nautical language. In this article such binomials as by and by, by and large, cut and run, etc. were described and the historic references were given as to their nautical/maritime origin. Altogether ten binomials were illustrated in the article.

The second group described in the article is phrasal verbs, which are treated as verb combination with an adverb or a preposition, or sometimes both, to give a new meaning. To be exact, we should talk about a postposition, not a preposition because the word occupies the place after, and not before the verb. Since our research lies in the proximity of nautical origin of such phrasal verbs, we picked up those that illustrate the nautical history of phrasal verbs, such as: to be taken aback, to go ahead, to fly a kite, to stand by, etc. Altogether fifteen phrasal verbs were illustrated in the article.

The third group considered in this article is pure idioms. It is always interesting for a researcher to find etymological roots of the expressions that we use nowadays. In the article we analyzed the definitions of such terms as "idiom", "colloquialism", "slang”, "phrasal verbs", "jargon etc.". While "colloquial" means a phrase or a word which is used in informal conversation, but not in formal speech ; "slang" is interpreted by many dictionaries as very informal, brand new, not very polite words used among particular groups of people; "phrasal verbs" as the term speaks by itself is a verb followed by a preposition (postposition word would be more correct) which changes the meaning of the whole phrase, sometimes drastically; "jargon" is specific vocabulary of different professions, (seafarers, doctors, lawyers); 'idiom' is something really different. We took the liberty to suggest our own definition to an "idiom". An idiom is an expression that simultaneously realizes two meanings: the direct one and the metaphorical one, but the second metaphorical meaning is contemporarily predominant and usually people immediately think about the metaphorical and not direct meaning when they hear an idiom. Idioms are the biggest bulk of the colloquial language of nautical origin researched; such idioms as hit the deck, between the devil and the deep blue sea, a drop in the ocean, double Dutch, etc. Altogether fifteen idioms were illustrated in the article. 
In future we consider the necessity of further research and description of contemporary colloquial English phrases - colloquialisms, idioms, phrasal verbs connected with sea and seafarers. We hope this article will be of use and interest not only to teachers of marine ESP and seafarers, but also to those who learn English in its evolution as a living organism.

\section{SUMMARY}

In this article we undertook an attempt to analyze and systematize the three groups of contemporary English colloquial phrases of nautical origin. It is essential for modern linguistics to reveal the etymological background of the language of today. In this article we tried to trace the roots of contemporary English colloquial phrases in the nautical language. We also analyzed the history of metaphoric transformation of primarily marine terms while they were entering the general colloquial English. The problem of researching the etymology of the language is always vital, because any language is a living organism that never stops developing. In our study we concentrated only on one professional niche - nautical language. We believe that such research would be fruitful in other professional domains. So far the materials studied in the article present the first attempt to deal with the problem of professional etymological studies in national linguistic science.

\section{References}

1. Hornby A.S. Oxford Advanced Learner's Dictionary of Current English. Oxford university Press, 2005. 1715 p.

2. Dictionary of English Language and Culture. London Group UK, 1992. $1528 \mathrm{p}$.

3. Random House Webster's College Dictionary. USA, 1995. 1555 p.

4. Walter W. Skeat, Concise Dictionary of English Etymology. Wordsworth Reference, 2007. 643 p.

5. Oxford Phrasal Verbs. Dictionary for learners of English. Oxford University Press, 2017. 398 p.

6. Jeans P.D. An Ocean of Words. A Dictionary of Nautical Words and Phrases. Toronto, Ontario : Carol Publishing Group, 1998. 180 p.

7. Opie I., Tatem M. Dictionary of Superstitions. Oxford, New York : Oxford University Press, 1996.

8. Beavis B., McGloskey R.G. Salty Dog Talk. The Nautical Origin of Everyday Expressions. London : Sheridan House ; New York : Granada, 1983. 96 p. 
9. Partridge Eric. A Dictionary of Historical Slang. UK : Penguin Books, 1977. $1065 \mathrm{p}$.

10. Nikulina O.L. Importance of Intercultural Awareness. Issues of Modern Philology in the Context of the Interaction of Languages and Cultures : International Scientific and Practical Conference. Ca' Foscari University of Venice, Italy, 2019. P. 138-141.

11.Nikulina O.L. Origin and Etymology of Marine Superstitions. Нова філологія : збірник наукових праць. Запоріжжя : Запорізький національний університет, 2020. № 80б. Т. II. С. 83-88.

12.Nikulina O.L. Nautical Origin of Contemporary English Colloquialisms. Innovative Pathway for the Development of Modern Philological Sciences in Ukraine and EU Countries : Collective Monograph. Wloclawek, Poland, 2021. Vol. 2. P. 120-139.

\section{Information about the author:}

Nikulina Olena Leonidivna, orcid.org/0000-0001-5206-5998

Candidate of Philological Sciences, Associate professor, Head of the English Department National University "Odesa Maritime Academy"

8, Didrichson str., Odesa, 65001, Ukraine 